\title{
Higher fibre and lower fat intake is associated with better vascular function in children with type 1 diabetes
}

\author{
Sarah Toome ${ }^{1 *}$, Jemma Anderson 2,3 , Jorien Schokker ${ }^{3}$, Oana Maftei $^{2}$, Roger Gent ${ }^{4}$, Christine Mpundu-Kaambwa ${ }^{5}$, \\ Jennifer Couper ${ }^{2,3}$, Alexia Peña ${ }^{2,3}$
}

From 8th APPES Biennial Scientific Meeting

Darwin, Australia. 29 October - 1 November 2014

Children with type 1 diabetes (T1D) might not consume a healthy diet. A healthy diet is associated with reduced risk of cardiovascular disease (CVD) in adults, but there is no data evaluating the association between diet composition and early markers of CVD in T1D children. We aimed to investigate the macro/micronutrient intakes of T1D children and the relationship with vascular function.

The Australian Child and Adolescent Eating Survey (ACAES-version1.2) Food Frequency questionnaire [1] was administered to 77 T1D children (aged $14 \pm 2.3$ years, 37 males, BMI z-score $0 . \pm 0.6$ ) participating in an RCT [2], obtaining in-depth macro/micronutrient intake. Vascular function was measured by Flow Mediated Dilatation (FMD) and Glyceryl Trinitrate Mediated Dilatation (GTN). Pearson's correlation and multivariate regression analysis determined dietary predictors of vascular function.

Children had diabetes duration $5.7 \pm 3.9$ years, median HbA1c 8.7(range: $6.3-14$ )\% and insulin dose $0.8 \pm 0.2$ units $/ \mathrm{kg} /$ day. 37 children used CSII.

T1D children had daily energy intake 10762.3 $\pm 2487.68 \mathrm{~kJ}$, protein $113.3 \pm 27.68 \mathrm{~g}$, fat $88.16 \pm 88.16 \mathrm{~g}$, carbohydrate $318.60 \pm 75.97 \mathrm{~g}$, fibre $31.41 \pm 8.89 \mathrm{~g}$ and sodium $3069.91 \pm 766.43 \mathrm{mg}$. Better (higher) FMD independently correlated with a higher daily fibre intake $\left(\mathrm{r}^{2}=0.25\right.$, Coefficient $0.20, \mathrm{p}=0.04$ ). Higher daily total fat intake independently correlated with worse (lower) GTN (other GTN associations in Table 1). Daily sodium intake exceeded recommendations of $1500 \mathrm{mg}$, this was not significantly related to FMD/GTN.

Higher fibre and lower total fat intake, is associated with better vascular function in T1D children. This is

'Women's and Children's Hospital, Department of Nutrition, North Adelaide, SA, Australia

Full list of author information is available at the end of the article
Table 1. Independent predictors of GTN

\begin{tabular}{lll}
\hline $\mathrm{R}^{2}=0.41$ & & \\
\hline & Coefficient & p-value \\
\hline Total fats & -0.06 & 0.02 \\
\hline Vessel diameter & -68.15 & 0.00 \\
\hline Diastolic BP & 0.23 & 0.04 \\
\hline Pump use & 3.35 & 0.01 \\
\hline T1D Duration & -1.26 & 0.04 \\
\hline
\end{tabular}

the first evidence that diet composition may reduce the risk of CVD in children with T1D in addition to improving diabetes control.

\section{Authors' details}

'Women's and Children's Hospital, Department of Nutrition, North Adelaide, SA, Australia. 'Women's and Children's Hospital, Endocrine and Diabetes Department, North Adelaide, SA, Australia. ${ }^{3}$ The University of Adelaide, Discipline of Paediatrics, North Adelaide, SA, Australia. ${ }^{4}$ Women's and Children's Hospital, Department of Medical Imaging, North Adelaide, SA, Australia. ${ }^{5}$ Women's and Children's Hospital, Research and Evaluation Unit, North Adelaide, SA, Australia.

Published: 28 April 2015

\section{References}

1. Watson JF, Collins CE, Sibbritt DW, Dibley MJ, Garg ML: Reproducibility and comparative validity of a food frequency questionnaire for Australian children and adolescents. Int J Behav Nutr Phys Act 2009, 6:62.

2. Alman AC, Talton JW, Wadwa RP, Urbina EM, Dolan Lm, Daniels SR, et al: Cardiovascular health in adolescents with type 1 diabetes: the SEARCH CVD study. Pediatr Diabetes 2014, 15(7):502-510.

doi:10.1186/1687-9856-2015-S1-026

Cite this article as: Toome et al: Higher fibre and lower fat intake is associated with better vascular function in children with type 1 diabetes. International Journal of Pediatric Endocrinology 20152015 (Suppl 1):O26. 